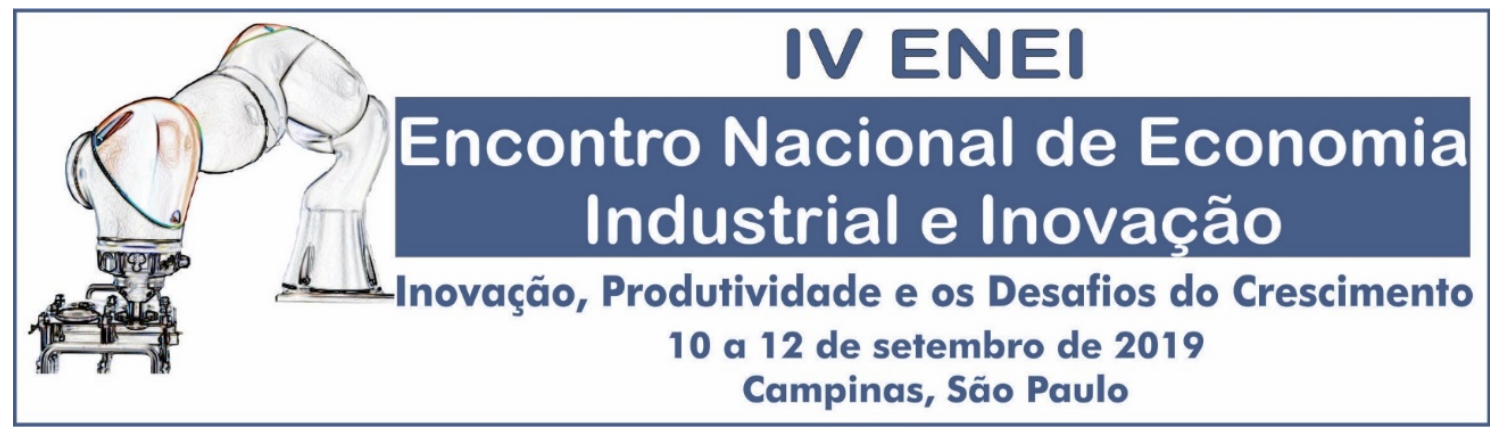

\title{
$O$ esgotamento do crescimento brasileiro e o investimento em infraestrutura enquanto novo vetor de dinamismo
}

André Bueno ${ }^{1}$

Fernando Sarti ${ }^{2}$

Resumo: O atual padrão de crescimento brasileiro, calcado no consumo, atingiu seu limite. Os baixos patamares de investimento nas últimas décadas Brasil é um dos principais fatores para o pequeno dinamismo da economia e uma indústria inadequada ao processo de desenvolvimento, especialmente com uma estrutura produtiva incapaz e insuficiente (desindustrialização precoce) de absorver os estímulos de demanda gerados pela economia. Assim, como forma de analisar tais hipóteses, efetuase neste trabalho comparações: (i) das participações e contribuições de países e regiões no PIB e investimento global; (ii) entre os padrões de crescimento brasileiro (consumption-led) e chinês (investment-led), e suas respectivas estruturas produtivas. Os resultados obtidos corroboram que o investimento é a causa fundamental para o pífio desempenho da econômica brasileira, fazendo-se fundamental o protagonismo do investimento para a retomada do crescimento. Este trabalho propõe, então, que a expansão dos investimentos em infraestrutura é um meio viável para tal tarefa.

Palavras-chave: Crescimento econômico; Estrutura produtiva; Investimento; Investimento em infraestrutura; Desindustrialização.

Abstrat: The current pattern of Brazilian growth, based on consumption, has reached its limit. The low levels of investment in the last decades Brazil is one of the main factors for the small dynamism of the economy and an industry inadequate to the development process, especially with an incapacitated and insufficient productive structure (early deindustrialization) to absorb the stimuli of demand generated by the economy. As a way of analyzing these hypotheses, in this work are made comparisons of: (i) the participation and contributions of countries and regions in global GDP and investment; (ii) between brazilian (consumption-led) and chinese (investment-led) growth patterns and their respective production structures. The results obtained corroborate that investment is the fundamental cause for the meager performance of the Brazilian economy, making the central role of investment for the resumption of growth. This work proposes, then, that the expansion of investments in infrastructure is a viable means for such task.

Keywords: Economic growth; Production structure; Investment; Investment in infrastructure; Deindustrialization.

Área temática: 1. Indústria e competitividade: 1.4 Padrões de especialização produtiva e desenvolvimento

JEL: O00, O11, O25

\footnotetext{
${ }^{1}$ Mestre e doutorando em Teoria Econômica pelo Instituto de Economia da Universidade Estadual de Campinas (IEUNICAMP). E-mail para contato: andrecbueno17@gmail.com.

2 Professor doutor do Instituto de Economia da Universidade Estadual de Campinas (IE/Unicamp). E-mail: fersarti@eco.unicamp.br.
} 


\section{Introdução}

O baixo nível de investimento no Brasil é um dos principais fatores para o pequeno dinamismo da economia nas últimas décadas. O fim do II PND simbolizou o esgotamento de um vigoroso ciclo de crescimento, a qual possuía alta participação do Estado e do investimento público, como elementos centrais que ancoravam a trajetória da economia e sustentavam o patamar do investimento total. As transformações pelas quais o país atravessou durante as décadas de 1980 e 1990 alteraram completamente as configurações dessa dinâmica. A perda da capacidade de implementação de investimento por parte do Estado (1980) e a redução de seu tamanho com o processo de liberalização (1990) minaram sua atuação e o volume dos investimentos públicos. Esse processo aguardava que os investimentos privados seriam capazes de liderar o processo de crescimento, apoderando-se do protagonismo do Estado com base nas premissas de maior eficiência econômica. Entretanto, tal fato não se procedeu no Brasil. O que de fato se observou foi uma nítida queda do nível de investimento e, por conseguinte, da taxa de crescimento brasileira.

O Brasil, que outrora era tido como um dos maiores emergentes, verificou a ascensão de outros países, como os Tigres Asiáticos, a China e a Índia. Apenas em um breve momento, no período Lula, o país aparentou que o ciclo de crescimento seria duradouro e significativo, fato que não perdurou e resultou na maior crise econômica da história brasileira. O padrão de crescimento, calcado no consumo, atingiu seu limite. Os baixos níveis de investimento ocasionaram uma indústria inadequada ao processo de desenvolvimento. O elevado coeficiente de importações nos períodos de crescimento, e as recorrentes crises no balanço de pagamentos são sintomas de uma estrutura produtiva incapaz e insuficiente de absorver e responder aos estímulos de demanda gerados pela economia, especialmente inserido em um contexto de desindustrialização precoce. Faz-se fundamental um protagonismo do investimento na atividade econômica para a retomada do crescimento.

Embora seja utópico pensar que o Brasil possa apresentar uma participação do investimento no PIB em patamares chineses, uma participação próxima ao da Índia se demonstra plausível e necessária para um maior desenvolvimento industrial e tecnológico e, assim, a obtenção de um ciclo virtuoso de crescimento. O grande desafio brasileiro é, portanto, tornar o investimento no vetor de dinamismo da economia. Este trabalho propõe, então, que a expansão dos investimentos em infraestrutura, tendo em vista suas características de gasto autônomo, por conseguinte, de sustentador e de indutor do investimento e da demanda agregada, é um meio viável para tal tarefa.

Dessa forma, o objetivo desta pesquisa é demonstrar como o baixo nível de investimento no Brasil é atualmente o maior entrave à retomada do crescimento. Para tal, o trabalho está dividido em quatro seções, mais esta introdução e uma conclusão. Procurar-se-á na primeira seção demonstrar como o Brasil está inserido na conjuntura internacional no que concerne à sua relevância no PIB e no investimento global nas últimas décadas. Assim, é verificado a evolução tanto das participações como das contribuições à taxa de crescimento do PIB e investimento global dos países e regiões entre 1990 e 2016, demonstrando que os detentores dos maiores níveis de dinamismos possuem elevados patamares de investimento. Por sua vez, a segunda seção aborda, dentro do mesmo recorte temporal (1990-2016), a importância dos padrões de crescimento na trajetória das economias, delimitando-se especialmente em Brasil e China. Essa seção tem o propósito de exibir os impactos das discrepâncias entres os padrões de crescimento destes países, e suas respectivas repercussões na estrutura produtiva e na trajetória de longo prazo. Na terceira seção é exposto os impactos da desindustrialização precoce no Brasil, e de como esta desdobra-se negativamente na competitividade e no crescimento econômico do país. Além do mais, esse processo decorre fundamentalmente em virtude dos baixos patamares de investimentos no país nas últimas quatro décadas. E na quarta seção, graças ao baixo dinamismo da atividade econômica, sugere-se que a expansão dos investimentos em infraestrutura é um meio viável para o Brasil obter a elevação da taxa de investimento e de crescimento. 


\section{Um panorama sobre o desempenho econômico do Brasil em um contexto internacional}

Após um fim e um início de milênio conturbado, o Brasil apresentou, a partir de 2003, um período ímpar de sua história, em razão de conciliar taxas significativas de crescimento e evoluções no âmbito social. Embora outrora o Brasil tenha apresentado um crescimento econômico exacerbado (Milagre Econômico), nunca antes em sua história a conciliou com relevantes avanços sociais. Entretanto, desde 2015, o país presencia uma das suas maiores crises da sua história, tanto política como econômica. Atualmente, a atividade econômica apenas apresenta espasmos de uma retomada do crescimento, tornando-se um estímulo estéril para um crescimento duradouro. Essa conjuntura acarreta demasiados impactos negativos, tanto na esfera econômica como na social, o que simboliza uma quebra do ciclo vivenciado anteriormente, nos anos 2000.

Esse movimento da taxa de crescimento não se restringiu ao caso brasileiro, visto que tem sido, também, um fenômeno de escala mundial. Assim, constata-se intenso paralelismo da trajetória brasileira com a trajetória mundial. O mundo, como um todo, vivenciou durante os anos 2000, um contexto extremamente próspero, por apresentar: taxas de crescimento globais a níveis históricos; intensificação do comércio internacional; e abundante fluxo de divisas entre as diversas economias (Gráfico 1). O principal fator para esse acontecimento foi o crescimento elevado dos EUA e, principalmente, da China. A conciliação desses crescimentos com o tamanho de suas economias ocasionou tal desfecho. Além do mais, a alta dos preços das commodities no ínterim possui elevada correlação com o crescimento desses países por estes serem grandes importadores de commodities, o que resultou na criação de um vetor de dinamismo nas economias periféricas. Esse é o caso brasileiro, o qual desfrutou do fato de ser um exportador de commodities e conservar uma estreita relação com tais países ${ }^{3}$.

Gráfico 1: Taxa média anual do crescimento do PIB (em \%)

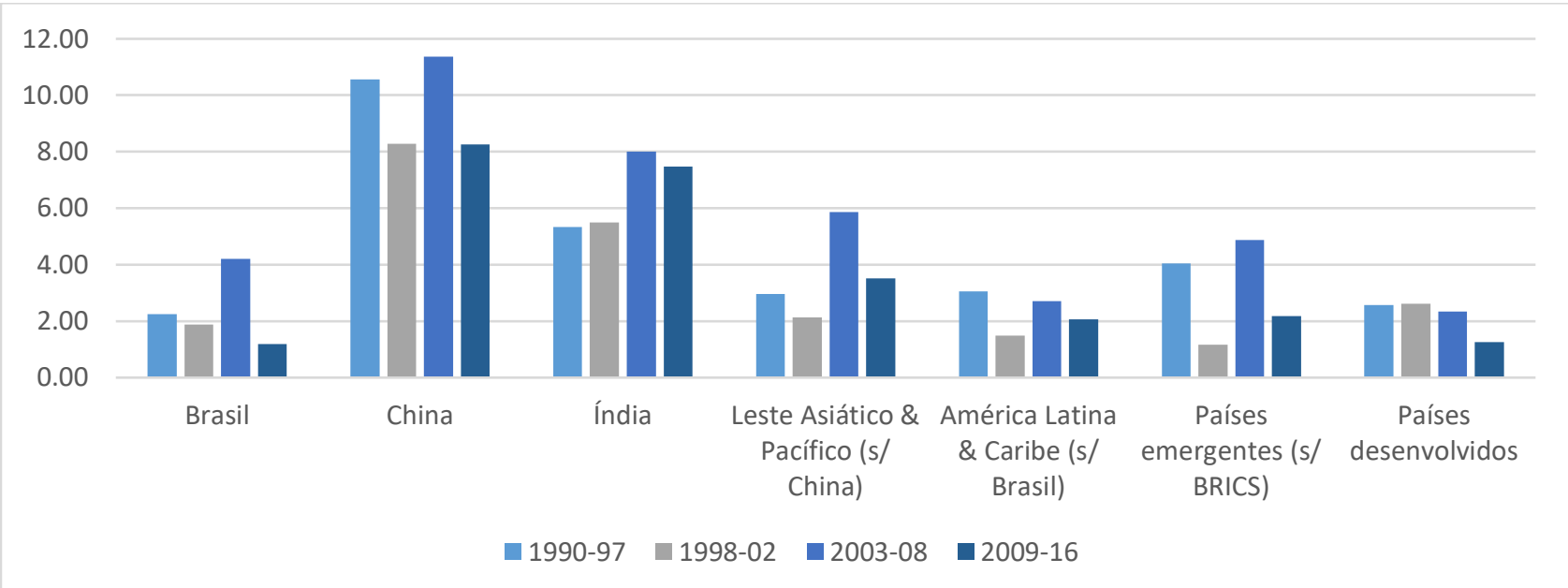

Fonte: World Bank, elaboração própria. As classificações utilizadas seguem as especificações do World Bank.

Entretanto, o mundo adentrou com a crise do subprime em uma conjuntura de crescimento atenuado, principalmente comparado ao período anterior. Esse ambiente próspero transfigurou-se em um comércio global estagnado com patamares baixos de investimento e crescimento. Tal conjuntura é agravada com as situações políticas em diversos países, as quais acarretam incertezas fortes sobre as expectativas futuras (KOSE et al, 2017). Faz-se necessário destacar que China e Índia destoam dessa análise, uma vez que continuam a apresentar crescimentos econômicos robustos, principalmente a China, com uma taxa de crescimento exemplar há mais de trinta anos. Esta vivencia, então, um momento histórico completamente antagônico ao brasileiro.

\footnotetext{
${ }^{3}$ Inicialmente o país possuía uma maior relação comercial com os EUA. Posteriormente, ocorreu um maior estreitamento com a econômica chinesa graças ao seu elevado dinamismo e à elevada demanda pelas exportações brasileiras.
} 
No que concerne ao Brasil, verifica-se que, tanto nos períodos de alta como nos de baixa, o desempenho se apresentou inferior aos dos demais países emergentes; especialmente no intervalo pós-crise, em virtude de sua elevada desaceleração e recessão a partir de 2012. Mesmo que o país aparentasse não sentir os efeitos e ser um dos primeiros países a sair da crise do subprime, tal fato não ocorreu ao longo do tempo. Os principais elementos para isso foram um padrão de crescimento calcado no consumo e as condições da estrutura produtiva brasileira que, embora o Brasil tivesse um dos maiores parques industriais do mundo, este se apresentava significativamente defasado em relação às economias desenvolvidas. Isso resultou num elevado coeficiente de importação de produtos de alto conteúdo tecnológico. No período pós-crise do subprime, essa situação se acentuou. A conciliação de uma economia aquecida e de uma taxa de câmbio valorizada fez com que parte das produções dos países afetados pela crise se destinassem ao Brasil, ocasionando demasiados aumentos no montante de produtos importados e a geração de expressivos déficits comerciais na indústria manufatureira. Portanto, observa-se no país um problema estrutural na indústria que vem se agravando ao longo do tempo e que, ao seu turno, acarreta a atenuação dos encadeamentos produtivos e um contínuo vazamento de demanda (renda) para o exterior (SARTI, 2015; HIRATUKA e SARTI, 2017).

Um dos fatores para tal acontecimento é, sem dúvida, o baixo nível do investimento em relação ao PIB. Desde o fim do II PND, os investimentos brasileiros se apresentam em níveis insuficientes, ocasionando adversidades para o crescimento econômico. Conforme reiterado por Furtado (1961), seja qual for o driver de dinamismo de uma economia (consumo, exportações ou investimento), para uma nação se desenvolver, faz-se necessário uma estrutura produtiva diversificada e sofisticada capaz de absorver e gerar novos estímulos de demanda e, assim, de renda. Dessa forma, como o único componente da demanda agregada que conserva a qualidade de expandir e de modernizar a estrutura produtiva é o investimento, o seu baixo patamar desdobra-se em uma trajetória de crescimento pífia e de tendência oscilante (stop-and-go) (MORCEIRO, 2018). A economia se encontra, nesse instante, em um estado de "equilíbrio do subdesenvolvimento", visto que a estrutura produtiva vigente não é capaz de atender à elevação da diversidade e complexidade que a procura perpassa no decorrer dos estágios, o que eleva os vazamentos dela e a sua fragilidade externa, tornando-se um ciclo vicioso.

Gráfico 2: Participação da Formação Bruta de Capital Fixo no PIB (em \%)

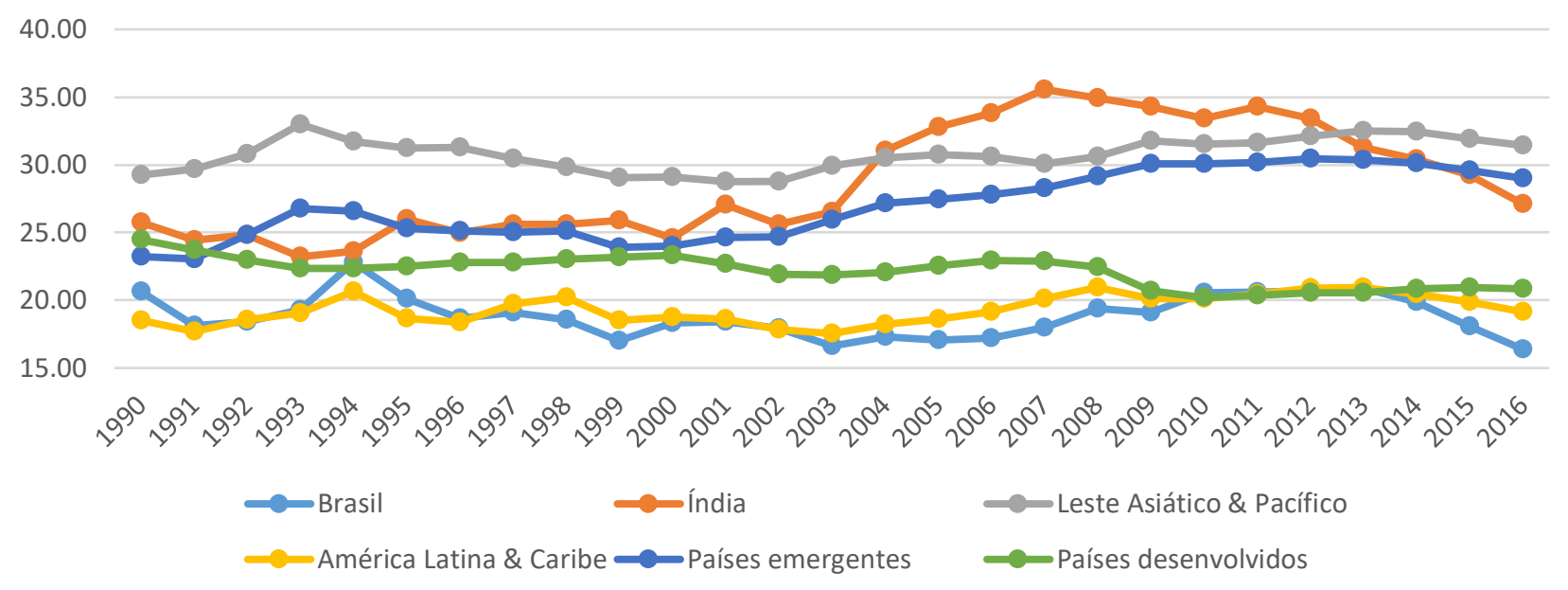

Fonte: World Bank, elaboração própria. As classificações utilizadas seguem as especificações do World Bank.

No Gráfico 2 pode-se observar como o patamar dos investimentos já se demonstrava abaixo da média global, muito antes à crise do subprime. Pode-se notar também, de como as participações do investimento no PIB influenciam na taxa de crescimento dos países e regiões (Gráfico 1). No caso de China, Índia e dos países do Leste Asiático, essa situação se demonstra nítida. A China é o país emergente de maior dinamismo nas últimas três décadas, tendo seu crescimento calcado em elevados níveis de investimento e em um crescimento abrupto de sua indústria. No período mais recente, a 
Índia vem apresentando elevadíssimas taxas de crescimento e, embora essa realidade seja baseada no consumo, apresenta elevadas taxas de investimento.

Esse panorama se torna ainda mais compreensivo ao se observar as evoluções dos países e regiões inseridos no contexto mundial por outra ótica: o das suas participações no PIB e no investimento global, e as suas respectivas contribuições para as taxas de crescimento, tanto do PIB como do investimento. Primeiramente, analisando-se a evolução do PIB mundial por participação, a magnitude da importância da China nesse processo é irrefutável (Gráfico 3). Conforme citado, nas últimas décadas a sua participação no PIB global cresceu descomunalmente, especialmente após os anos 2000, partindo de cerca de 2,2\% em 1990 para 12,25\% em 2016. No caso da Índia, a sua evolução citada é demonstrada pelo aumento de sua participação no PIB, atingindo 3,18\% em 2016 (em 1990 era de 1,23\%). Por sua vez, o Brasil apresentou certa constância nas últimas décadas, em torno dos 3\%, sendo que, após um leve aumento depois de 2008, a parcela que o país detinha retraiuse continuamente desde 2013, tendência essa agravada com a crise vivenciada pelo país no decorrer de 2015. Portanto, em pouco mais de vinte e cinco anos o Brasil não elevou a sua importância na participação do PIB global, o que retrata sua estagnação no período.

Gráfico 3: Participação dos países e categorias selecionadas no PIB global (em \%)

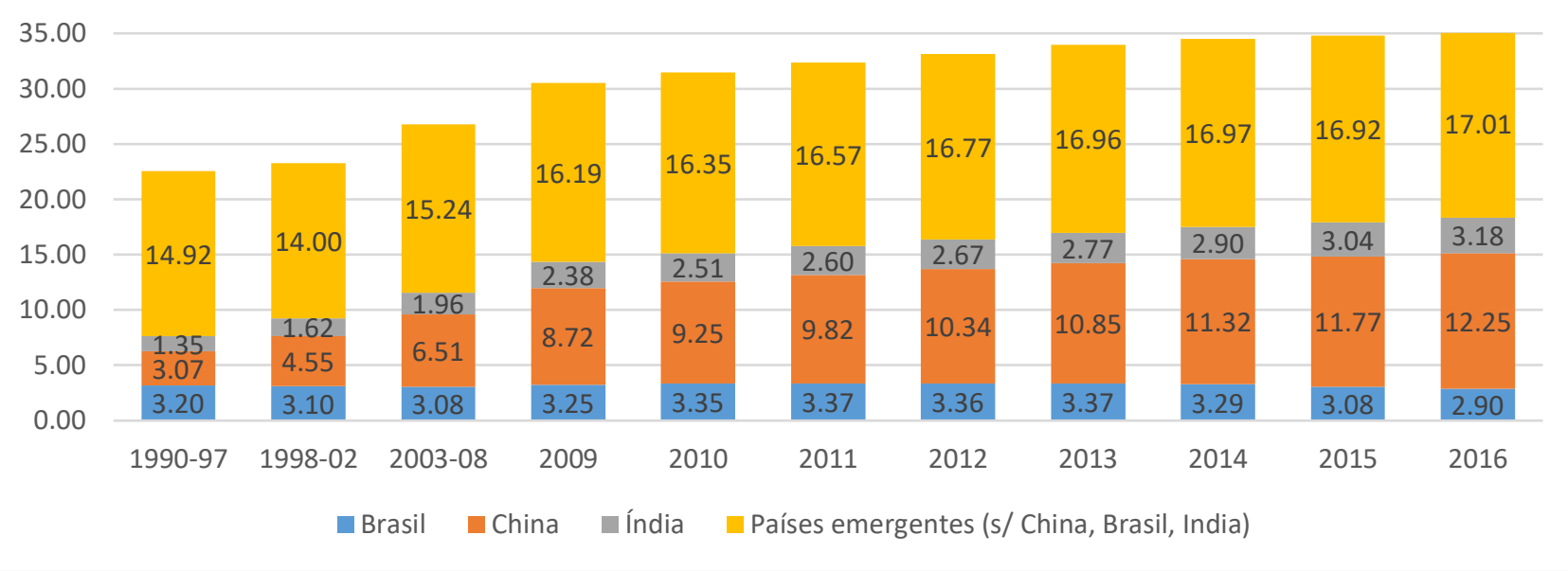

Fonte: World Bank, elaboração própria. As classificações utilizadas seguem as especificações do World Bank.

Os demais países emergentes também se apropriaram de uma maior parcela do PIB global, mas de forma mais tímida. Assim, nota-se que a perda de participação das economias avançadas decorre majoritariamente do crescimento monumental da China e, em pequena parcela da Índia. Os outros países que compõem os BRICS não apresentaram elevações significativas nas suas participações, e o mesmo pode ser dito dos demais países emergentes (Gráfico 3).

Esse movimento de apropriação por parte da China da parcela do PIB mundial é verificado na participação dos países na taxa de crescimento do PIB (Gráfico 4). A contribuição da China na taxa de crescimento global beira os 20\% entre 1991-2016 e atinge, no período de 2010-2016, um pouco menos de 30\%. No que concerne aos países desenvolvidos, opostamente à China, o seu intervalo de maior contribuição foi de 1991 a 2008 (cerca de 64\%), ou seja, obtiveram seu ápice previamente aos efeitos da crise financeira. No período de 2010 a 2016, a contribuição cai para cerca de $43 \%{ }^{4}$.

\footnotetext{
${ }^{4} \mathrm{O}$ ano de 2009 representa um decrescimento muito intenso dessa categoria, quebrando a tendência.
} 
Gráfico 4: Contribuição dos países e categorias selecionadas para a taxa de crescimento global (em \%)

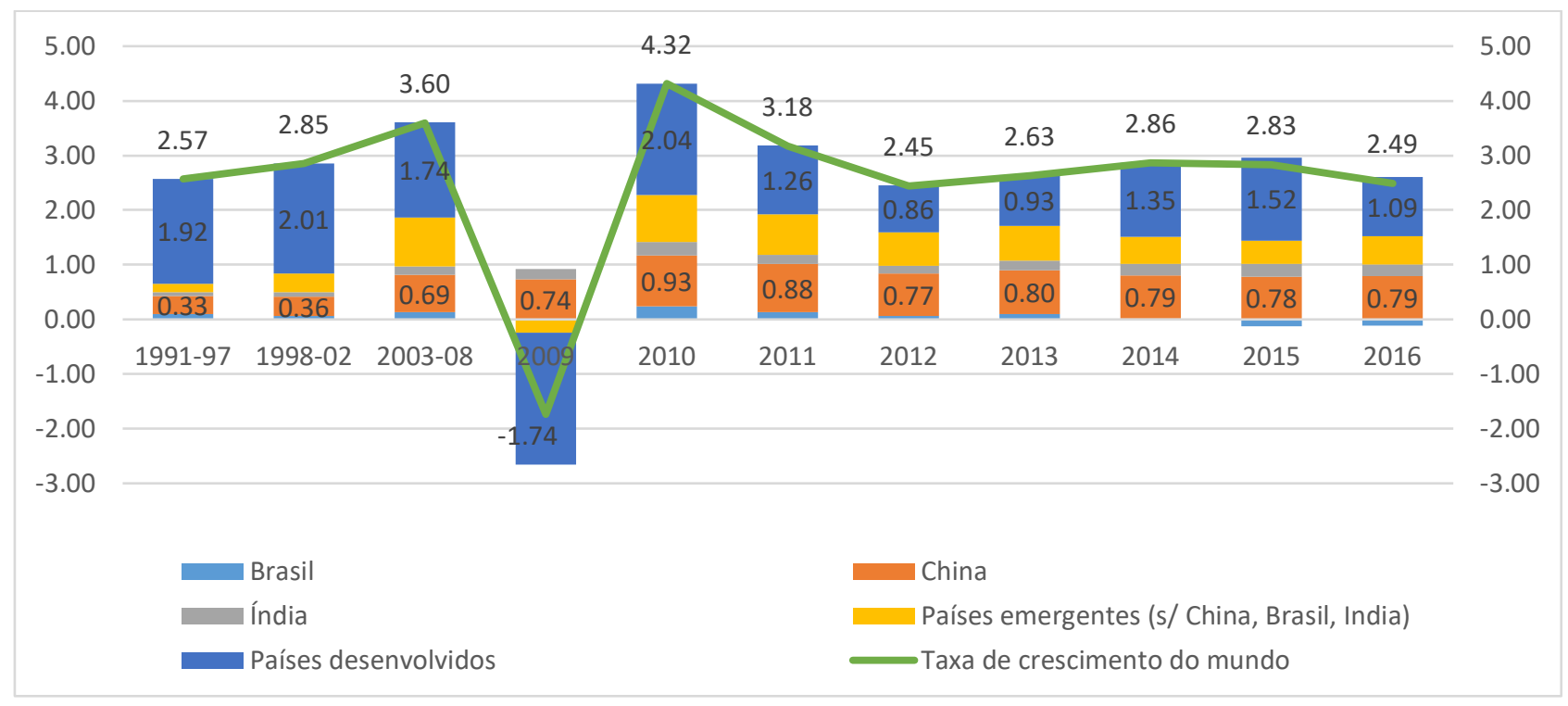

Fonte: World Bank, elaboração própria. As classificações utilizadas seguem as especificações do World Bank.

De forma semelhante à dinâmica temporal chinesa, a Índia apresenta uma elevação da sua contribuição para a taxa de crescimento do PIB global, que são indícios do ciclo de expansão vivenciado pelo país atualmente. O Brasil, como retratado anteriormente, exibiu elevação de sua contribuição entre 2003-2013, reflexo de seu ciclo de expansão; contudo, a reversão desse ciclo alterou tal tendência, tornando a sua contribuição negativa em 2015 e 2016. Desse modo, os desdobramentos da crise financeira à taxa de crescimento mundial são nítidos, pois, basicamente todos os países do globo apresentaram uma desaceleração nas suas taxas de crescimento, registrandose alguns casos mais atenuados (China) e exceções (Índia).

No caso da evolução do investimento, mais uma vez a China detém posição de destaque, sendo a elevação da sua participação no investimento global ainda mais abrupta que no PIB global, pulando de uma parcela de 0,66\%, para 22,96\% em 2016 (Gráfico 5). É uma transformação colossal em um intervalo de vinte e sete anos, ultrapassando a participação da América do Norte e fica um pouco abaixo de Europa \& Ásia Central (Gráfico 6). Bem como a China, a Índia também apresenta um aumento, partindo de 1,26\% em 1990 para 3,88\% em 2016.

Gráfico 5: Participação dos países e categorias selecionadas na Formação Bruta de Capital Fixo global (em \%)

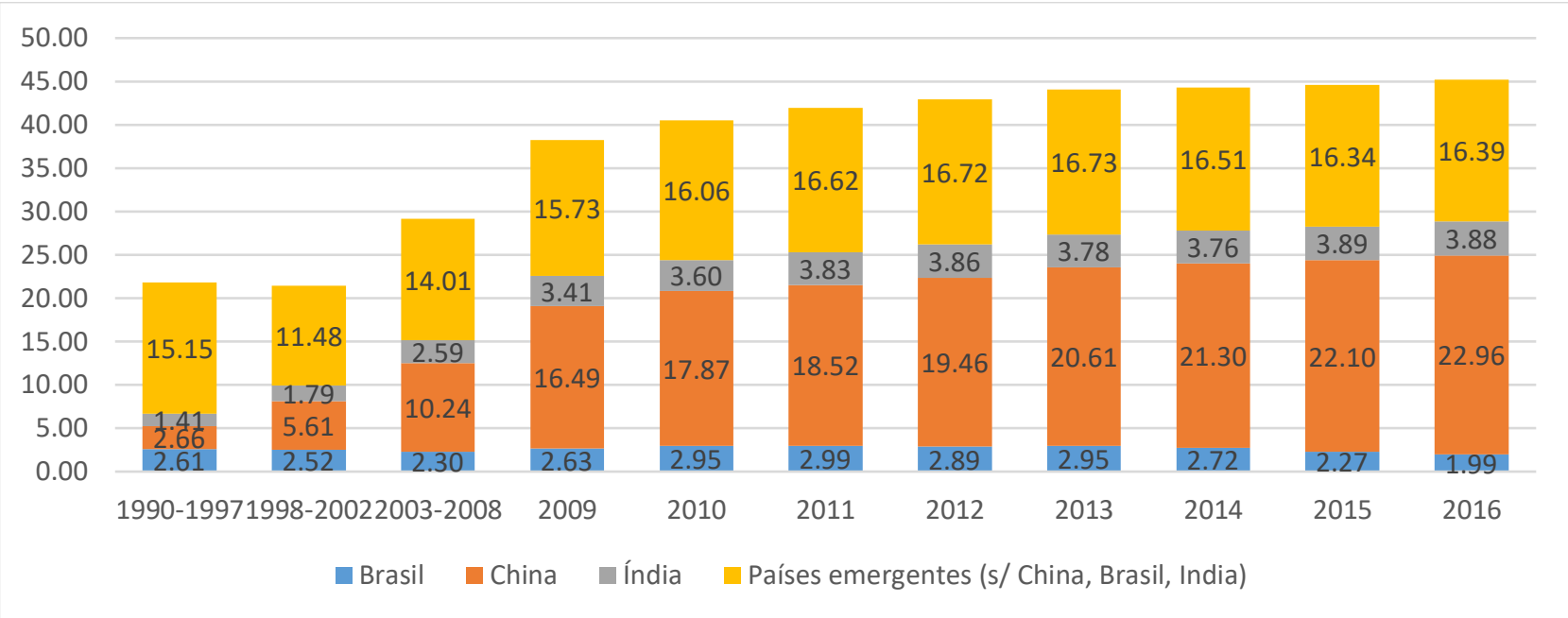

Fonte: World Bank, elaboração própria. As classificações utilizadas seguem as especificações do World Bank.

No caso do Brasil, novamente o país demonstrou uma redução, de 2,27\% em 1990 para 1,99\% em 2016. Após a tendência de aceleração dos investimentos a partir de 2007 e elevação da relação 
FBCF/PIB, - com ganhos na participação global, atingindo como pico o ano de 2011 (2,99\%) - o país aparentava adentrar em um ciclo de expansão dos investimentos. Todavia, esse ciclo perdurou até 2013, desacelerando-se em 2014 e em decadência em 2015 e 2016. O caso dos demais países emergentes na participação do investimento global se assemelha ao PIB, apenas demonstrando pequenos aumentos de suas parcelas.

Gráfico 6: Participação das regiões selecionadas na Formação Bruta de Capital Fixo global (em \%)

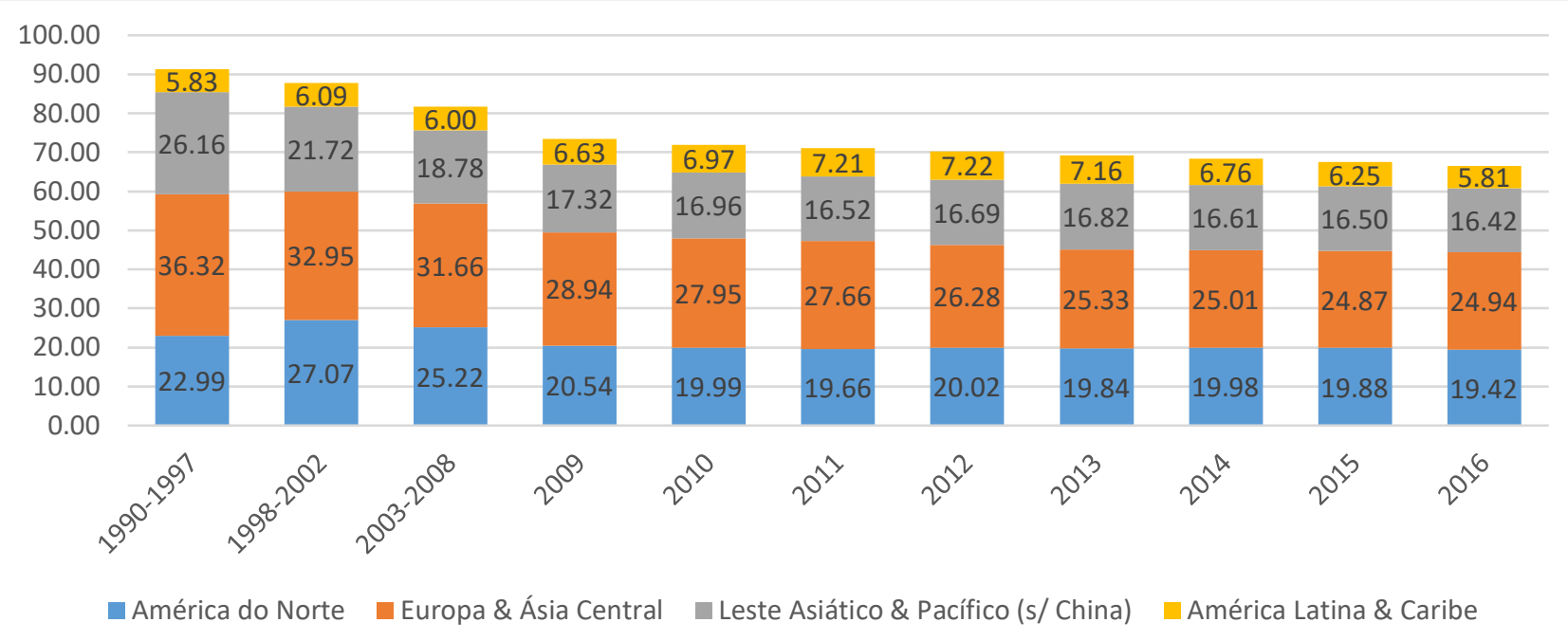

Fonte: World Bank, elaboração própria. As classificações utilizadas seguem as especificações do World Bank.

Em uma ótica regional, observa-se outra vez o impacto da transformação chinesa por meio da redução da participação da América do Norte e, principalmente, da Europa \& Ásia Central, uma vez que a última detinha cerca de 42,52\% do investimento mundial em 1990 (Gráfico 6). No caso do Leste Asiático \& Pacífico (s/ China), verifica-se considerável perda de participação ao longo do intervalo, o que indica que a região não avançou tanto neste âmbito mesmo com taxas de crescimento superiores às demais regiões (Gráfico 1) ${ }^{5}$. A América Latina \& Caribe, por sua vez, mesmo apresentando uma melhora no decorrer do período, de 4,91\% em 1990 para 5,81\% em 2016, desde 2013 a participação da região está diminuindo, retendo como principais fatores a atenuação do comércio internacional, a deterioração dos termos de troca, aumento das instabilidades políticas e, especialmente, a crise brasileira.

Analisando à taxa de crescimento do investimento global por contribuição dos países e regiões, verifica-se a origem do expressivo crescimento da China na participação do investimento global. Por certo, a contribuição da China para a taxa de crescimento da FBCF global é sem igual, atingindo no período, uma média de 50\% de contribuição (Gráfico 7). A contribuição média da Índia, no período, é em torno de 4,55\%, elevando-se significantemente após os anos 2000 . No âmbito regional, constata-se que a contribuição média do Leste Asiático \& Pacífico (s/ China) é de 4,75\%, patamar muito semelhante ao da Índia. O período de 1998-2002 é extremamente negativo para essa região, retratando a crise vivenciada nesse intervalo, visto que a sua contribuição, a partir de 2010, é de 13,83\%. Já a América Latina \& Caribe e Brasil seguem uma trajetória similar: suas contribuições médias no período são de $3,25 \%$ e $2,34 \%$, respectivamente. Em ambos os casos, após um ciclo de expansão dos investimentos, especialmente entre 2003-2008, derivados do boom de commodities, a região apresenta desde 2014 resultados desfavoráveis, quase sempre com contribuições negativas na taxa de crescimento da FBCF global. No caso brasileiro, em todos os anos, principalmente em 2015 e 2016.

\footnotetext{
${ }^{5}$ Isto se deve, provavelmente, a esses país possuírem seus crescimentos pautados nas exportações.
} 
Gráfico 7: Contribuição dos países e regiões selecionadas para a taxa de crescimento da FBCF global (em \%)

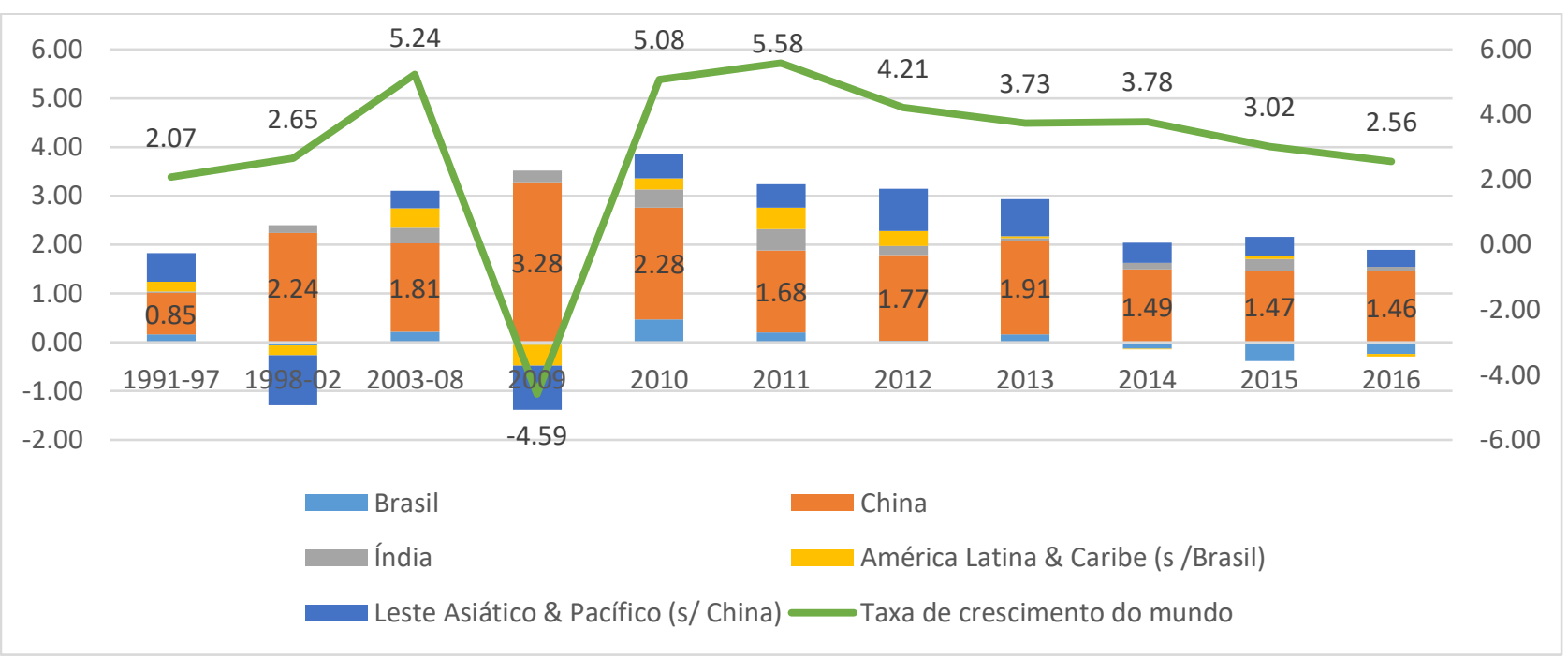

Fonte: World Bank, elaboração própria. As classificações utilizadas seguem as especificações do World Bank.

As evoluções das participações e contribuições dos países e regiões indicam que, desconsiderando-se a China e, de forma relativa, a Índia, a estrutura global permaneceu estável ao longo do período. Os países emergentes não conseguiram obter maior importância no cenário mundial, mesmo que a distância relativa tenha se reduzido no período, mas a absoluta ainda se mostra abissal. Para o caso especifico do Brasil, a distância em relação ao centro que, outrora fora reduzida, voltou a aumentar. Após a economia adentrar aparentemente um ciclo oportuno ao desenvolvimento, o país caiu na maior crise de sua história. Um cenário completamente antagônico ao vivenciado atualmente por China e Índia.

Especificamente para o caso de Brasil e China, embora existam inúmeras distinções, seja por aspectos econômicos, sociais e demográficos, ambos os países detinham, no início da década de 1990, participações similares, tanto no PIB como no investimento global. Todavia, as suas trajetórias no decorrer das décadas subsequentes, são dispares. O padrão de crescimento em que estes países estão inseridos e o desenvolvimento de suas estruturas produtivas possuem um grande poder de explanação para tal acontecimento. Portanto, faz-se fundamental compreender esses fatores e as respectivas distinções entre os países, tornando-se possível a realização de um diagnóstico das adversidades brasileiras e da implementação de certas medidas para o enfrentamento delas.

\section{Padrões de crescimento e estrutura produtiva}

É interessante notar as discrepâncias entre os padrões de crescimento nos diversos países do globo e de como essas diferenças impactam suas trajetórias de longo prazo. A ascensão econômica vivenciada por grande gama dos países asiáticos contém, como causa fundamental, a sua economia voltada para fora, ou seja, economias export-led. Há uma vasta literatura que enfatiza que esse tipo de crescimento seria o mais indicado às economias em desenvolvimento. Esse é o caso da teoria novo desenvolvimentista, visto que ao se efetuar as políticas econômicas recomendadas, possibilitaria a superação de entraves estruturais clássicos, como os estrangulamentos no balanço de pagamentos e a necessidade de investimentos externos (BRESSER-PEREIRA et al, 2017).

De acordo com essa teoria, o processo de desenvolvimento tradicional (cepalino) acarreta uma dependência de fluxos externos no decorrer do tempo, visto que possui como fonte de dinamismo a demanda doméstica. As políticas desenvolvimentistas empregadas no Brasil, voltadas para o setor interno, não teriam superado a principal adversidade do desenvolvimento que é a vulnerabilidade externa (doença holandesa) ${ }^{6}$. A necessidade de maiores volumes de investimentos (via importações) para o desenvolvimento industrial, e uma elasticidade renda crescente das importações no decorrer

\footnotetext{
${ }^{6}$ Para uma maior exposição da teoria novo desenvolvimentistas, olhar Bresser-Pereira et al (2017).
} 
do processo de desenvolvimento, com as transformações da procura, geram constantes pressões no setor externo do país, que ocasionam crises recorrentes no balanço de pagamentos. Dessa forma, o crescimento voltado para as exportações resultaria na criação de uma poupança externa e, por conseguinte, o fim de crescentes déficits estruturais na balança de pagamentos e da vulnerabilidade externa. A manutenção de uma taxa de câmbio competitiva estimularia a expansão das exportações e do setor industrial, tornando essa demanda externa o driver do crescimento.

Entretanto, conforme demonstrado na seção anterior, os países com os maiores crescimentos nas últimas duas décadas possuem seu padrão de crescimento calcado na demanda doméstica, que são Índia (consumo) e China (investimento). As características demográficas e territoriais devem ser consideradas, e os países necessitam analisar todas suas peculiaridades para a escolha de um padrão de crescimento, não se limitando ao enquadramento de um específico driver no processo de desenvolvimento.

Para o caso do Brasil, o nível insuficiente de investimento reflete no padrão de crescimento brasileiro, o qual é fortemente calcado no consumo e possui apenas lampejos dos demais componentes da demanda agregada por certos intervalos de tempo (Gráfico 8). Esse é o caso do investimento que, posteriormente a contribuições basicamente nula no intervalo de 1998-2002, tornou a apresentar certa importância a partir dos anos 2000, sobretudo no período de 2004-2008 e em 2010, ano de intensa retomada do crescimento após a crise, que retinha como um elemento importante os investimentos autônomos em infraestrutura. Contudo, de 2011 em diante, sua contribuição foi sendo atenuada.

Gráfico 8: Brasil - contribuição das variáveis de demanda agregada (consumo das famílias, formação bruta de capital, consumo do governo e setor externo) para o crescimento do PIB (em \%)

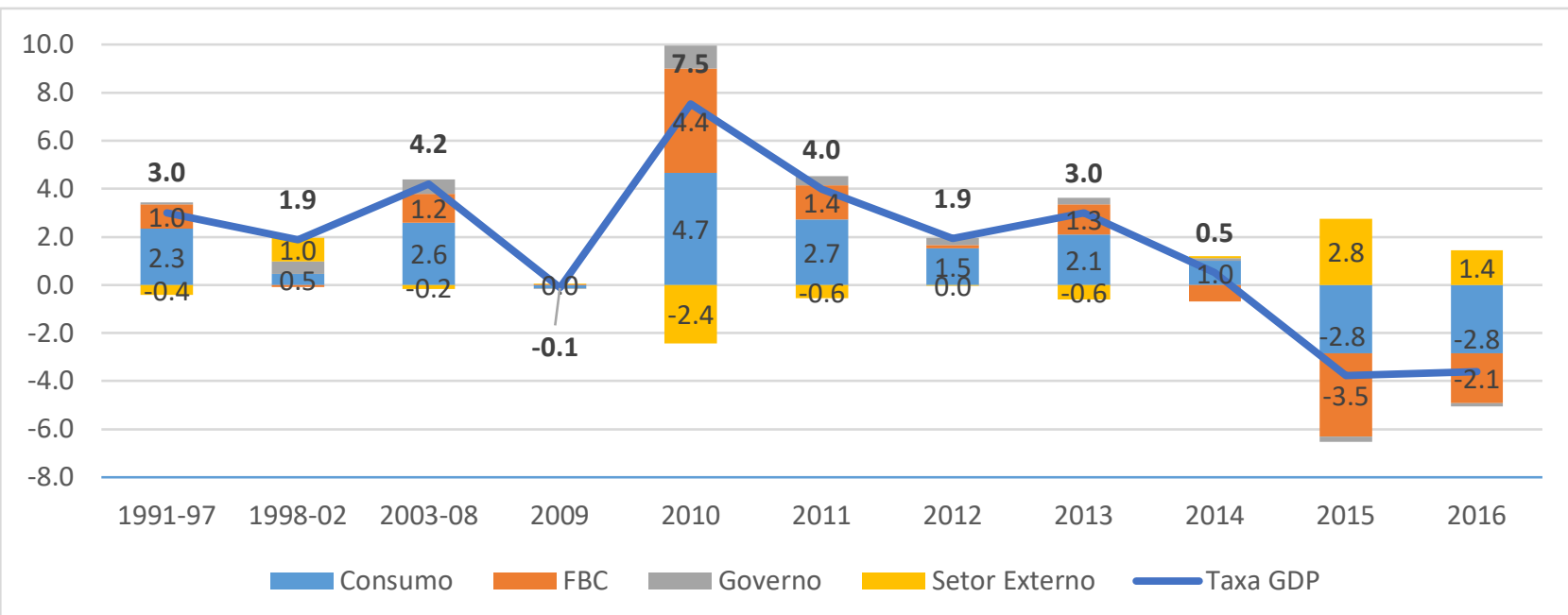

Fonte: World Bank, elaboração própria. As classificações utilizadas seguem as especificações do World Bank.

O desempenho do setor externo no Brasil é em grande parte negativo no intervalo, pois apenas no decorrer dos anos 2000, com o boom das commodities, apresentou uma pequena contribuição. O aquecimento do mercado internacional, com o crescimento chinês e os termos de troca favoráveis aos países exportadores de commodities, permitiu por um breve intervalo de tempo desempenhos satisfatórios do setor externo brasileiro. Entretanto, bem como no caso do investimento, a crise de 2008 resultou efeitos adversos ao setor externo, visto que o Brasil aumentou seu coeficiente de importação de forma demasiada (SARTI \& HIRATUKA, 2017). Ressalta-se que o desempenho positivo do setor externo está relacionado majoritariamente a períodos de crise e de baixo crescimento do país, ou seja, as quedas das importações possuem maior importância no processo que as elevações das exportações, como no caso de 2015 e 2016

Portanto, pode-se sintetizar que o crescimento brasileiro foi fundamentado no consumo, por possuir como fatores determinantes a elevação do emprego, aumento real do salário mínimo, expansão do crédito e aumento das transferências de renda, o que proporcionou efeitos multiplicadores de renda e de emprego para a economia. Desenrolou-se nessa conjuntura econômica 
- de um padrão de crescimento puxado pelo consumo, baixo nível de investimento e de elevação das importações, especialmente no que concerne aos produtos manufaturados - "um processo de fragilização e perda de dinamismo e de competitividade da indústria brasileira. " (SARTI, 2015, p.530). Esse processo de fragilização da indústria nacional, principalmente após a crise financeira, é explicado por uma gama de elementos, tanto internos como externos.

No âmbito interno, a aquecida atividade econômica impulsionada pelo dinamismo do consumo, juntamente com a sucessiva valorização cambial, resultou elevações das importações e reduções da competitividade da indústria e de seus setores exportadores. Além do mais, o aumento da produção manufatureira, que é majoritariamente voltada para o mercado interno, foi baseado, em grande parte, pelo aumento das importações de insumos intermediários. Como consequência, as relações intersetoriais foram atenuadas em virtude do maior coeficiente de importação de insumos comercializáveis, e não de ganhos tecnológicos e de produtividade (MORCEIRO, 2012). Os baixos níveis de investimento, como os de infraestrutura, impediram a expansão da capacidade produtiva e a elevação da competitividade da indústria, minando ainda mais a competitividade nacional. No âmbito externo, a alteração do quadro internacional ocasionou um agravamento das adversidades internas. A intensa queda do comércio internacional e a elevação de sua concorrência, particularmente dos produtos manufaturados dos países asiáticos, foram elementos que enfraqueceram o desempenho da indústria de transformação do Brasil ${ }^{7}$.

De fato, tal tendência é notada por meio do Gráfico 9, ao se comparar a trajetória brasileira à chinesa. A economia brasileira apresentou, desde a crise de 2009, uma significativa queda do setor industrial e dos investimentos na participação do PIB, retratando o período de vazamentos de demanda via importações. A perda do dinamismo da indústria e a queda dos investimentos não implicaram quedas da participação brasileira no produto industrial global, que se manteve constante no período de acordo com Sarti (2015). Todavia, essa conjuntura oculta alguns desdobramentos da evolução da indústria brasileira, especialmente ao se analisar separadamente os setores que a compõem.

Os setores de bens de consumo duráveis, sobretudo automobilístico, e alguns bens não duráveis (alimentos) apresentaram desempenho favorável. Por outro lado, os setores produtores de insumo, partes, peças e componentes para bens finais (têxteis, química, eletrônica, autopeças) e o setor de bens de capital (máquinas e equipamentos mecânicos e elétricos) perderam participação na estrutura industrial. (SARTI, 2015, p.526)

Esse retrato da economia brasileira era esperado, visto que a inserção do país às cadeias globais de valor demonstrava-se fragilizada. Sarti e Hiratuka (2017) verificam que essa conjuntura se agravou após a crise do subprime, com uma maior deterioração da estrutura produtiva brasileira e de sua inserção externa. Outros autores como Carneiro (2010) e Morceiro (2018) expõem que determinados setores comportam-se como maquiladoras ${ }^{8}$, caso do setor de bens de capital, enquanto a indústria Extrativa e certos subsetores da indústria de transformação apresentavam competitividade.

Contrariamente, na economia chinesa o investimento elevou-se demasiadamente desde os anos 2000, partindo de uma taxa de 35\% do PIB para em torno de 45\% em 2013. De acordo com Medeiros (2010), essa elevação do investimento provém do forte processo de urbanização, dos volumosos investimentos em infraestrutura e na indústria pesada ${ }^{9}$, acarretando a manutenção da participação do produto industrial e manufatureiro no PIB em níveis elevadíssimos e a ampliação e modernização da estrutura produtiva (Gráfico 9). Esse processo proporcionou uma elevação da competitividade da nação. A magnitude do desempenho industrial da China pode ser constatada pela

\footnotetext{
${ }^{7}$ Para maiores detalhes, ver Sarti \& Hiratuka (2017).

${ }^{8}$ Tal tendência fora agravada no decorrer da década de acordo com Morceiro (2018), percorrendo o rumo descrito por Sarti e Hiratuka (2017).

${ }^{9}$ Apenas uma pequena parcela dos investimentos está relacionada aos setores exportadores.
} 
evolução da sua participação no produto manufatureiro mundial, passando de 2,6\% em 1990 para 15,3\% em 2010 e, dessa forma, superando Alemanha e Japão, mantendo-se atrás apenas dos EUA.

Gráfico 9: Participação da formação bruta de capital fixo, produto industrial e manufatureiro no PIB (em \%)

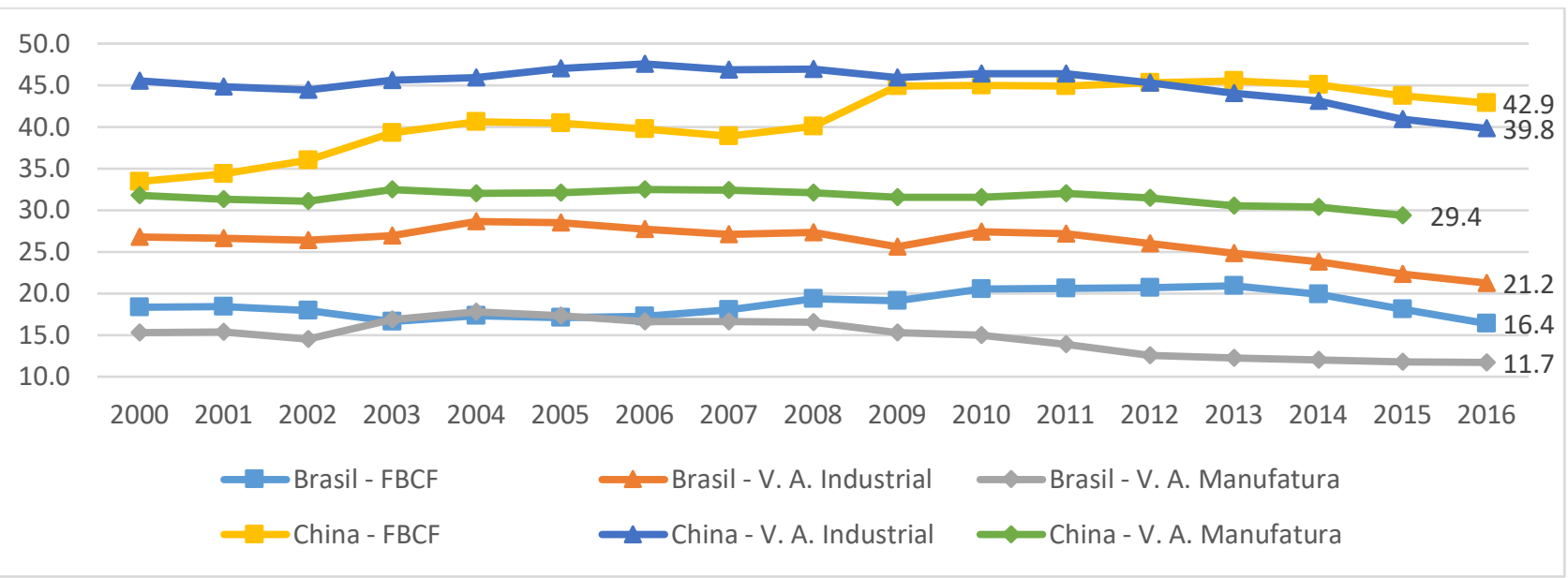

Fonte: World Bank, elaboração própria. As classificações utilizadas seguem as especificações do World Bank.

Ao verificar o processo de crescimento da China, com a finalidade de compreender as razões para tamanha discrepância entre as trajetórias de crescimento e as modificações na estrutura produtiva entre os países, constata-se uma grande diferença nos padrões de crescimento. Ao passo que o padrão brasileiro é calcado no consumo, o padrão chinês está fundamentado no investimento, sendo este o responsável por cerca de 50\% do crescimento da China entre 1991-2016. Como se pode constatar, embora o setor externo apresente certa relevância para o crescimento, especialmente no intervalo de 2003-08, este não é o vetor de dinamismo de sua economia. As exportações chinesas possuem elevado conteúdo importado ${ }^{10}$, o que atenua a capacidade de geração de valor agregado e de encadeamentos produtivos e tecnológicos. Além disso, desde a crise do subprime, a redução é amplificada em virtude da queda do comércio internacional.

Gráfico 10: China - contribuição das variáveis de demanda agregada (consumo das famílias, formação bruta de capital, consumo do governo e setor externo) para o crescimento do PIB (em \%)

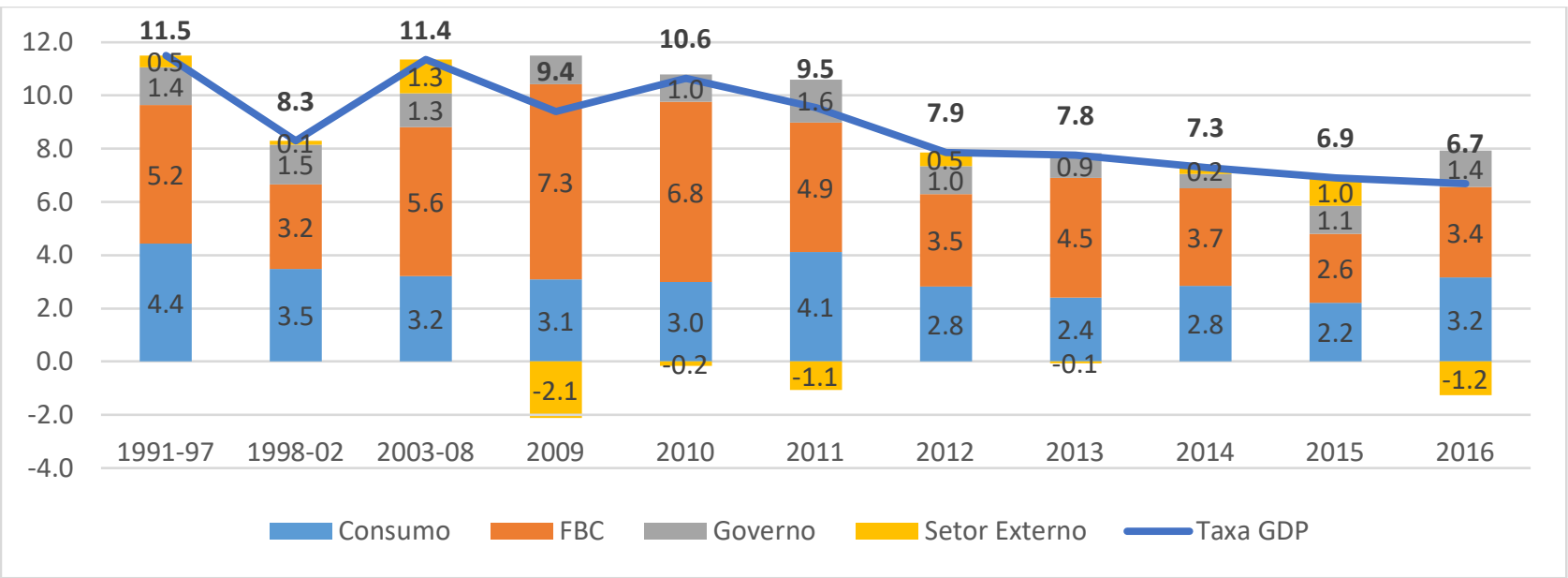

Fonte: World Bank, elaboração própria. As classificações utilizadas seguem as especificações do World Bank.

No entanto, torna-se imprescindível destacar que, o setor externo, pode ser um elemento importante para a dinâmica dos investimentos, devido as interrelações presentes nos componentes da demanda agregada. A título de exemplo, por a economia chinesa ser um grande importador de commodities, essa exerce relevante impacto na estrutura produtiva e nos investimentos do país. $\mathrm{O}$ mesmo pode ser descrito para o seu crescente vetor de produtos manufaturados exportados ao longo

${ }^{10}$ Os setores de equipamentos elétricos e eletrônicos se enquadram nesse caso. 
dos anos, uma vez que cria estímulos de demanda (externo) para a efetuação de novos investimentos e, assim, a ampliação e modernização da estrutura produtiva ${ }^{11}$.

De todo modo, o vetor fundamental da economia chinesa foi seu elevado volume de investimentos. As características do investimento, isto é, a sua capacidade de promover uma demanda por bens industriais e a sofisticação da estrutura produtiva, possibilitaram a intensificação dos encadeamentos produtivos, resultando assim, na elevação da participação industrial na economia e de seu desempenho em escala mundial (SARTI, 2015).

\section{Os desdobramentos da desindustrialização no Brasil}

Nessa seção procurar-se-á expor a vinculação entre a perda de competividade e dinamismo da economia brasileira com o processo de desindustrialização que esta perpassa atualmente, sendo um entrave para a retomada do crescimento econômico. Ademais, esses elementos estão fortemente relacionados, posto que a indústria é o centro dinâmico da atividade econômica, e é por meio dela que os transbordamentos de produtividade (desenvolvimento tecnológico) são difundidos para a economia, o que ocasiona a diversificação e expansão da estrutura produtiva, fator imprescindível para o desenvolvimento da nação. Embora haja uma extensa literatura sobre o debate de existência da desindustrialização brasileira, como os trabalhos de Hiratuka e Sarti (2017) e Morceiro (2012), este trabalho possui o enfoque em seus desdobramentos ${ }^{12}$.

Estudos como de Morceiro (2012 e 2018) e Drach (2016) constatam indícios relevantes de perda de competitividade graças a uma desindustrialização precoce da indústria brasileira. Inicialmente com Morceiro (2018), o autor destaca que a indústria de transformação vem sendo sucateada desde o início dos anos 1980. Uma amostra dessa realidade é a sua contribuição no valor adicionado em relação ao PIB. Para o caso do setor manufatureiro esse contexto torna-se ainda mais perverso. Assim, ambos os setores persistem em tendência de queda, percorrendo a contramão da trajetória esperada, uma vez que o país não atingiu o estágio de desenvolvimento e a maturação de sua economia. De acordo com o Morceiro (2012), há um processo desindustrialização precoce desde 2005, a qual foi agravado no triênio de 2009-2011 com elevação do coeficiente de importações. Em trabalho posterior, Morceiro (2018) indica a continuidade desse fenômeno nos anos posteriores, sendo que essa tendência ainda foi agravada.

Esses resultados corroboram à explanação de perda de dinamismo da economia e de elos produtivos no tecido industrial, em virtude do crescimento exponencial das importações, particularmente após a crise do subprime, conforme enfatizado por Sarti e Hiratuka (2017). Morceiro (2012 e 2018) chega a conclusão análoga e expõe, por meio do coeficiente de importações de insumos e componentes comercializáveis (CICC $)^{13}$, que a penetração das importações foi difundida pelos diversos setores que compõem a economia brasileira. A indústria de transformação demonstrou-se ser a mais impactada por essas importações, o que fundamenta a perda dos elos produtivos e o esgarçamento do tecido industrial. Quanto a composição dos insumos importados, Morceiro (2018) demonstra que os componentes de alto e médio-alto teor tecnológico (P\&D) angariaram grande participação no total.

Conforme citado, Sarti e Hiratuka (2017) afirmam que, apesar da perda de competitividade dar-se de forma heterogênea entre os setores, esta ocorreu com maior veemência nos mais intensivos

\footnotetext{
${ }^{11}$ Esse último exemplo é o contexto vivenciado pelos países asiáticos, que possuem as exportações como o vetor de dinamismo de suas economias. Embora esses países possam apresentar maiores contribuições nos demais componentes da demanda, é no setor externo que se encontra o vetor de dinamismo de suas economias.

${ }^{12} \mathrm{~A}$ efetuação do debate de desindustrialização, embora crucial, não está no escopo deste trabalho, fazendo com que a sua realização seja inviável.

${ }^{13}$ Uma vantagem desse índice é verificar apenas os insumos que possuem alguma concorrência internacionais, o que o torna um indicador menos viesado. Esse indicador foi utilizado também pelo autor para a mensuração do adensamento produtivo. Quanto maior for o CICC, menores serão os encadeamentos intersetoriais e, por consequência, a capacidade de geração de emprego e de renda da economia.
} 
em tecnologia, e os resultados obtidos por Morceiro (2012 e 2018) e Drach (2016) não escapam dessa lógica.

Para verificar a hipótese de desindustrialização da economia brasileira, Drach (2016) analisa a evolução das variações do emprego (absoluta e relativa) por meio da metodologia de decomposição estrutural $^{14}$ e adotando uma abordagem setorial. Primeiramente com a variação absoluta do número de empregados na economia entre 2003 e 2013, três efeitos se destacam: (i) efeito escala na demanda final; (ii) uma redução das importações para uso intermediário; (iii) e um aumento da produtividade/eficiência produtiva, a qual acarretou redução do emprego. Ao se analisar a variação absoluta do emprego por uma perspectiva setorial, nota-se que dentre os setores que obtiveram variações positivas, este decorreu de abruptos aumentos da demanda final, enquanto os que apresentaram variações negativas são derivadas de ganhos de eficiência produtiva/tecnológica (poupadora de empregos), concomitante a um processo de substituição de insumos importados por nacionais geradores de empregos.

Em termos relativos, as constatações obtidas por Drach (2016) revelam padrões relevantes para a compensação da evolução do emprego no Brasil no período recente e, consequentemente, na evolução da estrutura produtiva brasileira. Os setores que perderam participação no emprego total, possuem como elementos determinantes os ganhos de produtividade e a diminuição dos insumos importados. Nesse caso estão contemplados a Indústria Extrativa Mineral e, principalmente, a Agropecuária. Já os setores aos quais apresentam uma evolução na participação emprego foram aqueles que exibiram significativas reduções relativas de eficiência produtiva, aumento de uso de insumos importados e se beneficiaram da expansão da demanda final. Esses foram, em grande medida, os setores que compõem a indústria de transformação, sendo que dentro deste grupo, os de maior intensidade tecnológica exibiram quedas ainda mais intensas.

Portanto, conforme Drach (2016), enquanto para o caso da Agropecuária, observa-se uma "desindustrialização positiva", isto é, de perda absoluta no emprego total em virtude do aumento de eficiência produtiva, para o caso da Industria de Transformação e, também, Manufatureira, nota-se o oposto. Em outros termos, sob a ótica relativa, o processo de regressão produtiva nesses setores demonstra-se patente, posto que estes apresentaram ganhos de emprego em virtude de perdas de competitividade e de eficiência produtiva. Além do mais, embora o número de empregos tenha aumentado na Indústria, conjuntamente com sua participação no emprego total, este ocorreu, majoritariamente, graças a regressão tecnológica.

Como consequência desse processo, os postos de trabalho "perdidos" em razão do aumento da eficiência técnica além de serem deslocados para o setor de serviços, como esperado, também foram para o setor industrial. A atividade industrial, a qual deveria apresentar o mesmo movimento que o da Agropecuária, demonstrou uma "industrialização negativa", particularmente em termos relativos derivados da redução da eficiência produtiva comparativamente aos demais macros setores O setor que deveria ser o núcleo dinâmico da economia a termos cepalinos, com transbordamentos e difusões de produtividade e de avanços tecnológicos, foi aquele que deteve os menores dinamismos e exibiu um comportamento esperado pelo setor de serviços, isto é, de polo de atração de empregos e de baixo ganho de produtividade.

Embora Morceiro (2012) realize seu trabalho pela ótica da produção (valor adicionado) e do comercio exterior, este chega a conclusões semelhantes. $\mathrm{O}$ autor demonstra-se ainda mais veemente quanto a desindustrialização e a evolução negativa das Indústrias de média-alta e alta tecnologia. Além do mais, reitera a existência de indícios de contínua e intensa tendência à reprimarização da pauta exportadora. Dessa forma, considerável número de setores industriais já estariam próximos de

\footnotetext{
${ }^{14}$ No que se refere a decomposição, o autor a realiza com base em seis efeitos: dois referentes a demanda final, (i) efeito escala (variação do volume) e (ii) efeito composição (variação na estrutura interna da demanda); dois referentes ao efeito substituição, (iii) importações para uso final e (iv) importações para uso intermediário; (v) variação da tecnologia; (vi) variação dos estoques.
} 
atuar como maquiladoras, tendo em vista que os insumos comercializáveis utilizados no processo produtivo eram majoritariamente importados. Esse aumento configurou-se especialmente nos setores da indústria de transformação de médio-alto e alto conteúdo tecnológico. Já em trabalho posterior, Morceiro (2018) atualiza e amplia sua pesquisa por meio de uma abordagem setorial. Portanto, essa abordagem efetuada permitiu análises mais profundas e robustas do processo de desindustrialização, visto que tem a capacidade de delimitar os setores que sofrem o impacto da desindustrialização precoce, como o caso dos intensivos em tecnologia. Os resultados constatados são análogos (negativos) ao estudo prévio, sendo que estes apresentaram-se de forma ainda mais intensa.

Conforme Morceiro (2018), essa abordagem permitiu esquematizar os setores em três classificações. O primeiro se refere aos setores que passaram por uma desindustrialização normal/esperada, sendo estes predominantemente intensivos em trabalho e supridores de necessidades básicas. O segundo grupo, por sua vez, percorre uma desindustrialização precoce, como setores de máquinas e equipamentos e petroquímica. Por fim, o terceiro caso são de setores que não apresentam tendências de industrialização ou desindustrialização prematura. Nesse grupo estão incluídas atividades de elevada intensidade tecnológica, como por exemplo, os setores automobilístico, farmacêutico, informática e eletrônicos. Todavia, este grupo deveria estar apresentam ganhos de participação no PIB, o que não está ocorrendo.

Tal fato é mais precário no cenário brasileiro devido o adensamento produtivo ser menor em setores intensivos em tecnologia, ou seja, que são fundamentais para o desenvolvimento econômico. Nestes setores, o CICC encontra-se em patamares elevados, o que indica aumento do esgarçamento do tecido industrial. As atividades de alto e média-alto teor tecnológico tiveram baixo volume de exportações e alto patamar de CICC, enquanto os setores de baixa tecnologia e média baixa tecnologia o oposto. Exceção das atividades de alta tecnologia são a exportação de aeronaves (MORCEIRO, $2018)^{15}$. A indústria manufatureira brasileira não possui uma correlação positiva entre exportações e importações de insumos e componentes comercializáveis. Tal desfecho fortalece a hipótese de inserção reativa e tímida nas cadeias globais de valor.

Destarte, em conformidade com Morceiro (2018), a integridade da indústria é parcial ${ }^{16}$. Por ser um fator essencial para o crescimento e desenvolvimento econômico, esse cenário é preocupante tendo em vista que acarretaria uma deficiência estrutural da economia brasileira. Assim, como destacado inúmeras vezes, a importância da retomada do investimento para a recuperação da estrutura produtiva, e sua expansão e modernização é fundamental.

\section{5. $O$ investimento em infraestrutura enquanto sustentador e indutor do crescimento}

Como sublinhado nas seções anteriores, as discrepâncias entre os padrões de crescimento chinês e brasileiro explanam a trajetória do desenvolvimento dessas nações, e as distintas dinâmicas intersetoriais de suas respectivas indústrias. Assim, nota-se que um crescimento apenas calcado no consumo possui suas limitações, posto que sem uma estrutura produtiva adequada ocorrerão vazamentos de demanda por meio de importações, acarretando um processo de esgotamento do crescimento econômico e deterioração do parque industrial (desindustrialização precoce). Ademais, antagonicamente aos países exportadores asiáticos, um processo de crescimento baseado nas exportações também se demonstra inviável para o Brasil no nível atual de competitividade da estrutura produtiva.

A utilização das exportações como o driver principal do crescimento aparenta ser insuficiente, especialmente devido ao aumento da concorrência internacional, como no caso dos bens manufaturados. A situação estrutural do setor externo brasileiro não deverá se modificar a médio

\footnotetext{
${ }^{15}$ As importações de insumos e componentes intensivas em P\&D não foram transladados em maiores volumes de exportações, apenas em vazamentos de renda.

${ }^{16}$ Por esse fator Morceiro (2018) reitera a importância da abordagem setorial, impedindo que a análise efetuada não seja viesada pelo somatório das atividades, o que ocultaria resultados e informações relevantes do estado da indústria de transformação.
} 
prazo, já que a baixa competitividade sistêmica que a atual estrutura produtiva se encontra atenua a sua capacidade de potencializador da atividade econômica. De acordo com Sarti (2015, p. 534):

A elevação da competitividade sistêmica vai muito além de uma necessária desvalorização do real. Dependerá também de maiores investimentos em capacidade produtiva, Em PD\&I e em infraestrutura, da consolidação de grandes grupos nacionais com participação ativa e não subordinada nas cadeias regionais e globais de valor, de reformas institucionais, incluindo uma profunda reforma tributária, entre outros.

Desse modo, como no caso da China (investment-led growth), o investimento revela-se uma variável chave, possuindo a oportunidade de se tornar a força motriz para o crescimento do Brasil por causa de suas peculiaridades. O desafio brasileiro é, portanto, encontrar meios para a elevação desse investimento. Autores como Sarti (2015), Fleury (2009) e Dávila-Fernández destacam que os investimentos em infraestrutura possuem a capacidade e as características necessárias para a efetivação do aumento da participação do investimento no PIB.

O setor de infraestrutura alicerça e possibilita o funcionamento da atividade econômica por meio do fornecimento de ativos e insumos essenciais. As características específicas do setor de infraestrutura corroboram para sua utilização de sustentador e indutor de um processo de crescimento. É sustentador por ser considerado um gasto autônomo, alicerçando, portanto, a manutenção de níveis mais elevados tanto do investimento como da demanda agregada. É indutor por promover externalidades positivas para a atividade econômica, e elevar a demanda por bens e insumos de diversos setores, acarretando uma ascensão de suas rentabilidades, fator vital para o processo de inversão e, por conseguinte, de transformação da estrutura produtiva. Ademais, a expansão dos investimentos em infraestrutura ocasiona desdobramentos que não se delimitam à esfera econômica, pois abrange aspectos políticos e sociais. Indubitavelmente, no âmbito social, isso deriva da característica de ser um bem público em determinados casos e, ainda, da situação precária do setor de infraestrutura. Por certo, essa abordagem permite conciliar um avanço concomitante na frente econômica e social, ou seja, de crescimento econômico e redução da desigualdade (BIELSCHOWSKY, 2013).

Gráfico 11: Participação dos investimentos em infraestrutura no PIB (média entre 1992-2013, em \%)

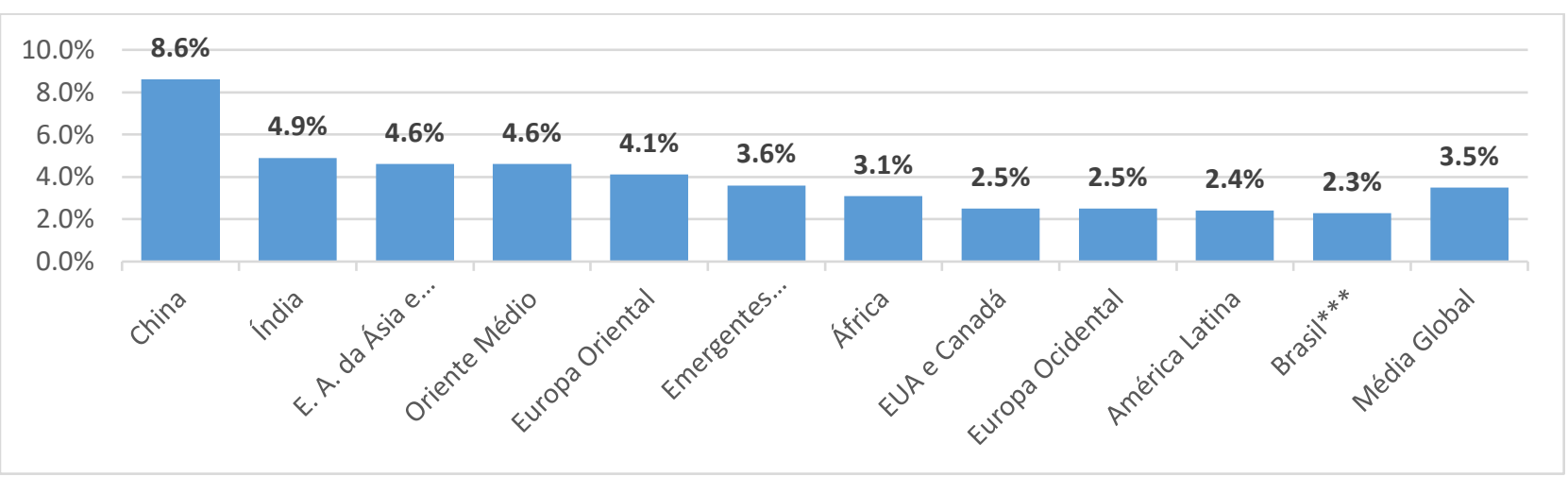

Fonte: Mckinsey Global Institute (2016) e Pereira e Puga (2016). Dados incluem apenas os investimentos em Transporte, Telecomunicações, Saneamento e Energia Elétrica. *Economias avançadas: Austrália, Hong Kong, Japão, Nova Zelândia, e Cingapura. **Bangladesh, Indonésia, Malásia, Paquistão, Filipinas, Sri Lanka, Taiwan, Tailândia e Vietnã. ***Período de 1992 a 2015.

No gráfico 11 é possível verificar o baixo investimento em infraestrutura realizado no país em comparação ao internacional, especialmente em países com um maior dinamismo de suas economias (China e Índia). O Brasil retém elevados déficits estruturais no setor que acarretam inúmeros desdobramentos negativos por toda a economia, incluindo a competitividade. Os investimentos em infraestrutura no Brasil são baixos comparativamente a média global, sendo até mesmo incapaz de repor o capital depreciado (PEREIRA \& PUGA, 2016). De fato, a precariedade em que se encontra o setor de infraestrutura é retratada no Gráfico 12 . O estoque de capital do setor é de apenas $16 \%$ do $\mathrm{PIB}$, mais de quatro vezes menor do que a média mundial, em torno de $70 \%$. O Brasil possui, portanto, 
um estoque de capital e investimentos menores comparativamente aos demais países em desenvolvimento ${ }^{17}$ (China, Índia, Polônia e África do Sul).

Gráfico 12: Total de estoque de capital no setor de infraestrutura em \% do PIB

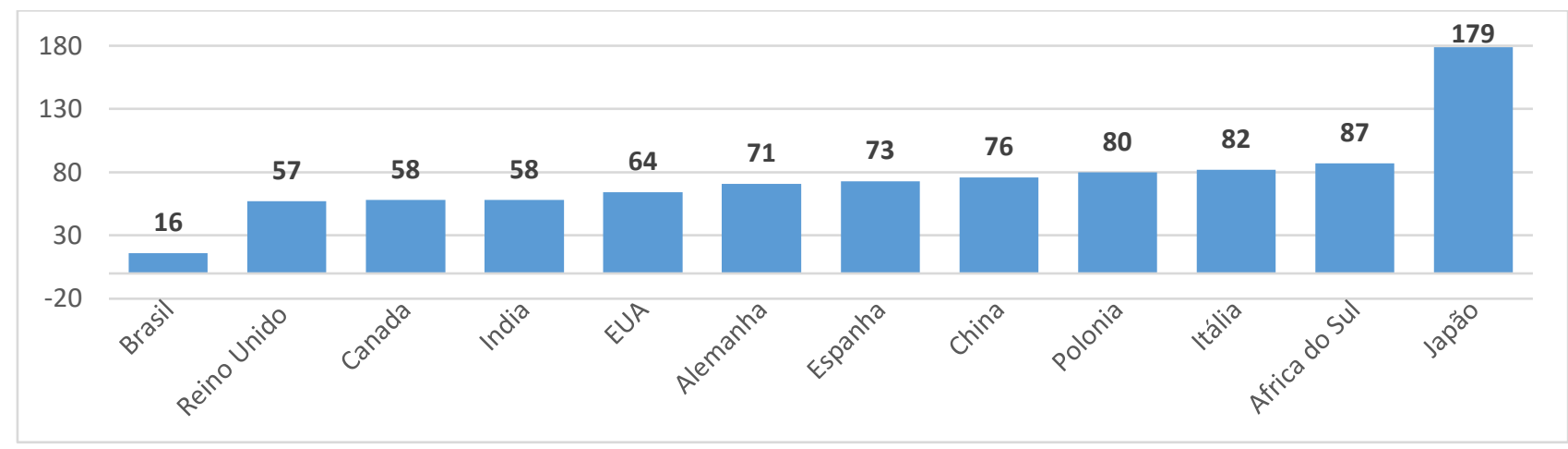

Fonte: Mckinsey Global Institute (2013)

Outra forma de visualizar tal quadro é por meio da Tabela 1, que demonstra as participações médias da infraestrutura na FBCF de países selecionados. Como pode ser verificado, o Brasil além de possuir uma das menores participações possui o nível mais baixo de FBCF, o que ocasiona um patamar ainda menor de investimentos em infraestrutura, comparativamente aos demais países. Tal discrepância ampliou-se nos últimos anos. Após o período recente de crescimento na década passada no governo Lula, que utilizou os gastos e investimentos públicos, dentre eles em infraestrutura (PACs), como um motor do crescimento, verificou-se a sua desaceleração no primeiro mandato Dilma, e sua completa ruptura com a alteração do quadro econômico e institucional, isto é, nos governos Dilma 2 e Temer (MELLO \& ROSSI, 2018).

Tabela 1: Participação dos investimentos em infraestrutura na FBCF nos países selecionados (média entre 1992-2015, em $\%)$

\begin{tabular}{ccc}
\hline Países & Part. Infra & FBCF \\
\hline Brasil & 12,2 & 18,9 \\
China & 21,9 & 38,6 \\
Índia & 16,9 & 29,1 \\
Cingapura & 15,3 & 30,0 \\
Coreia do Sul & 11,9 & 32,7 \\
África do Sul & 21,3 & 18,1 \\
Austrália & 15,4 & 26,0 \\
Canadá & 17,6 & 21,5 \\
Turquia & 13,5 & 27,1 \\
México & 11,9 & 21,9 \\
\hline
\end{tabular}

Fonte: Elaboração própria, com base nos dados do World Bank e Mckinsey Global Institute (2013,2016 e 2017). Para Turquia e México a média é entre 2008-2015 e Coreia do Sul 1992-2011.

Em conformidade com Lopreato (2013 e 2015), no decorrer do dos governos Lula 2 e Dilma 1 foi criado todo um aparato institucional que visava a retomada dos Planos Nacionais. Em outros termos, o fortalecimento de empresas públicas estratégicas, sejam elas de pesquisa (EPL - Empresa de Planejamento e Logística), financiamento (BNDES) e produção (Petrobrás, Telebrás, Valec e Eletrobrás), esboçavam o ensejo desses governos na retomada do Estado desenvolvimentista. Estes fatores representavam elementos de descontinuidade em relação às políticas adotadas nos mandatos

\footnotetext{
17 No que concerne às economias desenvolvidas, estas, em alguns casos, não empenham grandes inversões em infraestrutura, visto que essas nações realizaram a universalização da prestação dos serviços de infraestrutura previamente, ou seja, não necessitam dispender elevados montantes nesse setor, apenas modernizando-o e repondo o capital depreciado. Isso pode ser visualizado com base no estoque de capital no setor de infraestrutura que os países dispõem.
} 
FHC. Contudo, o aparato institucional criado vem sendo sucateado e extinto desde as alterações das diretrizes políticas, que culminaram no fim do PAC e na Emenda Constitucional 95 (EC95) em 2016 (DWECK et al., 2018). A EC95 simbolizou o "fim" dos gastos e, especialmente, do investimento público, como os de infraestrutura. As perspectivas de retomada desses investimentos permanecem incertas e pessimistas com a continuidade de pautas de austeridade fiscal nos anos subsequentes. Então, essa conjuntura agrava ainda mais o déficit estrutural brasileiro no setor de infraestrutura.

Destarte, a ampliação e modernização do setor de infraestrutura, aproximando-se dos patamares médios globais, possibilitariam diversos avanços para a economia brasileira. A maturação desses novos investimentos promoveria ganhos sistêmicos na competitividade e uma contínua demanda por bens industrias. Esse cenário é extremamente profícuo para o desenvolvimento industrial e tecnológico no Brasil, que nas últimas décadas apresentam significativa deterioração, sendo um enorme obstáculo ao desenvolvimento. Caso essa retomada se demonstrasse como a patamares alcançados na década de 1970, esses avanços seriam ainda mais intensos, permitindo a elevação do estoque de capital do setor, seus serviços e benefícios para a economia e sociedade. $\mathrm{O}$ Brasil, portanto, aproximar-se-ia do modelo de crescimento chinês e indiano, podendo adentrar num processo de crescimento duradouro e de elevado dinamismo como os destes países.

\section{Considerações Finais}

O presente trabalho procurou expor a centralidade do investimento para a retomada do crescimento econômico brasileiro. Desde o fim do II PND com a Crise da Dívida Externa, ou seja, há quase quatro décadas, o Brasil aparenta estar estagnado no seu processo de desenvolvimento, não conquistando qualquer protagonismo econômico em âmbito mundial, ao mesmo tempo em que assiste à ascensão de outras nações emergentes que se encontravam mais atrasadas, como a Índia e, especialmente, a China. Nestas últimas quatro décadas, mesmo com um crescimento abaixo do patamar internacional, apenas no período Lula (2003-2010) a economia aparentava retornar aos trilhos do crescimento. Esse ciclo, entretanto, não perdurou e foi sucedido pela maior crise econômica brasileira que ainda assola o país.

$\mathrm{O}$ vetor de dinamismo (consumo) da economia brasileira alcançou seu esgotamento, sendo que outros componentes da demanda agregada possuem suas limitações a curto e médio prazo (exportações), em virtude da baixa competitividade e deterioração da estrutura produtiva. Esse cenário da economia brasileira está altamente correlacionado com a desindustrialização precoce que o país enfrenta. Ademais, o acirramento da concorrência global nos produtos manufaturados é mais um entrave para o crescimento export-led.

Este trabalho, portanto, procura expor a importância do investimento em infraestrutura na qualidade de uma estratégia de desenvolvimento industrial de base, e sustentador e indutor do investimento e da demanda agregada. $\mathrm{O}$ investimento em infraestrutura pode não ser uma condição suficiente para o crescimento econômico, mas é, indubitavelmente, uma condição necessária. Conforme exposto, o baixo patamar de investimento é a causa fundamental para a deterioração da indústria e de seus encadeamentos intersetoriais, ocasionando uma estrutura produtiva inadequada para um processo de crescimento, antagonicamente ao caso da China, por exemplo. Por conseguinte, a elevação do estoque de capital (seus serviços) de infraestrutura a patamares médios internacionais, ainda mais em um país com um déficit estrutural tão forte como o do Brasil, proporcionaria um vetor de dinamismo vigoroso tendo em vista os elevados montantes de emprego e capital, isto é, de demanda e investimento que movimenta.

Entretanto, as perspectivas de expansão desses investimentos são pessimistas, visto que desde o segundo mandato Dilma o aparato institucional direcionado a medidas desenvolvimentistas vem sendo sucateada e extinta. Ademais, o novo governo eleito, Bolsonaro, demonstra o intuito de persistir e aprofundar as pautas de austeridade fiscal, o que resulta em maiores entraves a esse tipo de política econômica. 


\section{Referências Bibliográficas}

BIELSCHOWSKY, Ricardo. Estratégia de desenvolvimento e as três frentes de expansão no Brasil: um desenho conceitual. Texto para Discussão, Instituto de Pesquisa Econômica Aplicada (IPEA), 2013.

BRESSER-PEREIRA, Luis; OREIRO, José Luis; MARCONI, Nelson. Macroeconomia Desenvolvimentista: Teoria e política econômica do novo desenvolvimentismo. Elsevier Brasil, 2017.

CARNEIRO, R. Desenvolvimento brasileiro pós-crise financeira: oportunidades e riscos. Observatório da Economia Global, Textos Avulsos, n. 4, Agosto 2010.

DÁVILA-FERNÁNDEZ, Marwil Jhonatan. Desindustrialização e o investimento em infraestrutura como instrumento conciliador de uma política industrial base no Brasil. Brazilian Journal of Political Economy, v. 35, n. 3, p. 576-600, 2015.

DRACH, Daniel Chaves et al. Componentes estruturais da desindustrialização: uma análise da economia brasileira para o período 2003-13. Dissertação (Mestrado), Universidade Estadual de Campinas (UNICAMP), 2016.

DWECK, Esther et al. Impacto da austeridade sobre o crescimento e a desigualdade no Brasil. XXIII Encontro Nacional de Economia Política. Acesso em, v. 9, n. 01, p. 2018, 2018.

FLEURY, F.L. (2009), “Investimento em infraestrutura como instrumento de política industrial”, Tese (Doutorado em Administração) - Faculdade de Economia Administração e Contabilidade, Universidade de São Paulo, São Paulo, 206 pp.

HIRATUKA, Célio; SARTI, Fernando. Transformações na estrutura produtiva global, desindustrialização e desenvolvimento industrial no Brasil. Brazilian Journal of Political Economy/Revista de Economia Política, v. 37, n. 1, 2017.

KOSE, M. Ayhan et al. Weakness in investment growth: Causes, implications and policy responses. 2017.

LOPREATO, Francisco Luiz C. Aspectos da atuação estatal de FHC a Dilma. Texto para Discussão, Instituto de Pesquisa Econômica Aplicada (IPEA), 2015.

LOPREATO, Francisco Luiz Cazeiro. Caminhos da política fiscal do Brasil. Editora Unesp, 2013.

MCKINSEY GLOBAL INSTITUTE. Bridging global infrastructure gaps - Has the world made progress? McKinsey \& Company, out. 2017.

MCKINSEY GLOBAL INSTITUTE. Bridging global infrastructure gaps. McKinsey \& Company, jun. 2016.

MCKINSEY GLOBAL INSTITUTE. Infrastructure productivity: how to save $\$ 1$ trillion a year. McKinsey \& Company, jan. 2013.

MEDEIROS, C. A. O ciclo recente de crescimento chinês e seus desafios. Observatório da economia global, Centro de Estudos de Conjuntura e Política Econômica do Instituto de Economia/Unicamp, Textos Avulsos - n. 3, jun. 2010.

MELLO, Guilherme; ROSSI, Pedro. Do industrialismo à austeridade: a política macro dos governos Dilma. In: CARNEIRO, Ricardo; BALTAR, Paulo; SARTI, Fernando. Para além da política econômica. São Paulo: Editora Unesp Digital, 2018.

MORCEIRO, P. C. Desindustrialização na economia brasileira no período 2000-2011: Abordagens e indicadores. Dissertação (Mestrado) - Universidade Estadual Paulista, Faculdade de Ciências e Letras, Araraquara, 2012. 
MORCEIRO, P. C. (2018), “A indústria brasileira no limiar do século XXI: uma análise da sua evolução estrutural, comercial e tecnológica", Tese (Doutorado em Ciência Econômica) — Faculdade de Economia Administração e Contabilidade, Universidade de São Paulo, São Paulo, 216 pp.

PEREIRA, A.; PUGA, F. P. Infraestrutura no Brasil: ajustando o foco. Rio de Janeiro: BNDES, nov. 2016. (Textos para Discussão n.112).

SARTI, Fernando. Padrão de crescimento e desenvolvimento industrial. In: BARBOSA, Nelson et al. (Org.). Indústria e desenvolvimento produtivo no Brasil. Elsevier, 2015.

SARTI, Fernando; HIRATUKA, Célio. Desempenho recente da indústria brasileira no contexto de mudanças estruturais domésticas e globais. Campinas: Instituto de Economia Unicamp, 2017.

WORLD BANK - Disponível em <www.worldbank.org>. Acessado em 13/07/2018 